Evica Delova Jolevska ${ }^{1}$

American College Skopje, Macedonia

Ilija Andovski ${ }^{2}$

National Bank of The Republic of Macedonia
SCIENTIFIC REVIEW ARTICLE doi:10.5937/ekonomika1701051D

Received: January, 10, 2016

Accepted: January, 31, 2017

\title{
FINANCIAL INCLUSION: THE CASE OF REPUBLIC OF MACEDONIA
}

\begin{abstract}
The core goal of this paper is to assess the level of finacial inclusion in Republic of Macedonia. The level of financial incluison in a country is important because it can facilitate the reduction of poverty in a country. Aslo the higher level of financial inclusion can have positive impact on macroeconomic development by facilitating the economic growth. The main mechanisams are lower transactional costs and better distribution of capital. Also the level of financial inclusion is important for effective execution of other social policies. The level of financial inclusion in Macedonia is on satisfactory level which was driven by the legislation also. Almoust all the population have access to bank account which is good base for further measures. Still, the use of the account only to receive wage and withdraw from ATM indicates for higher need for financial education. Also, the new payment methods like credit cards or electronic payments are on very low level which further emphasizes the need for education in which the banks must have more active role. The borrowings in major part are from relative and friends and from retail stores. In all categories as less financially included are older people, people with smaller income and people how are less educated. This gives clear path for the policy makers where to focus its activities of enhancement of the level of financial education.
\end{abstract}

Key words: Financial inclusion, Financial access, Macedonia, comparative analazy

JEL classification: G21; G28

\section{ФИНАНСИЈСКА ИНКЛУЗИЈА: СЛУЧАЈ РЕПУБЛИКЕ МАКЕДОНИЈЕ}

\begin{abstract}
Апстракт
Суштински иฺиь овог рада је да се прочени ниво финансијског укључивање у Републиии Македонији. Ниво финансијске инклузије у земьи је важан, јер може да помогне сманеьу сиромаштва у земьи. Такође, виши ниво финансијске инклузије може да има позитиван утицај на макроекономски развој путем олакшавања економског раста. Главни механизми су нижи трансакциони трошкови и бољи
\end{abstract}

\footnotetext{
1 jolevski2001@yahoo.com

2iandovski@yahoo.com
} 
распоред капитала. Такође, ниво финансијске инклузије је важан за ефикасно извриавање других сочијалних политика. Ниво финансијске инклузије у Македонији је на задовољавајућем нивоу према важећим законима. Такође, сво становништво има приступ банковном рачуну. То је добра основа за даље мере. Ипак, употреба рачуна само за примање плате и подизање новца из банкомата указује на већу потребу финансијске едукације. Такође, нови методи плаћања као што су кредитне картице или електронска плаћања су на веома ниском нивоу, што додатно наглашава потребу за образовањем у којој банке морају да имају активнију улогу. Кредити се у највећем делу узимају од рођака и пријатеља као и из малопродајних објеката. У свим категоријама мање су финансијски укьучене старије особе, људи са мањим примањима и људи који су мање образовани. Ово даје јасан пут креаторима политике. Односно, на шта треба да фокусирају своје активности да би унапредили ниво финансијског образовања.

Кључне речи: Финансијска инклузија, финансијски приступ, Македонија, компаративна аналаза.

\section{Introduction}

Financial inclusion is one of the most used words lately in the academic and financial world. In simple words the financial inclusion has one main goal, to provide access to financial services to parts of the population that are still unbanked. This is part of the population with lower level of income, that lives in rural areas, that is part of the grey economy ect. For the World Bank financial inclusion means that individuals and businesses have access to useful and affordable financial products and services that meet their needs - transactions, payments, savings, credit and insurance - delivered in a responsible and sustainable way. Why is the financial inclusion important issue? Because the estimation is that 2 billion adults worldwide don't have a basic account (World Bank, 2016). Also, More than 200 million formal and informal micro, small and medium-sized enterprises (MSMEs) in emerging economies lack adequate financing to thrive and grow. The approach of The World Bank for addresing this issues focuses on 9 intertwined areas (World Bank, 2016):

- National financial inclusion strategies,

- Modernize retail payment systems and government payments,

- Reform national payments systems (NPS), including remittance markets

- Diversify financial services for individuals,

- Leverage technology for financial inclusion,

- Strengthen competition and expand access points,

- Financial consumer protection,

- Financial capability and

- Financial inclusion data.

The main reason for enhancment of the level of financial inclusion is to reduce poverty. It is seen by policymakers as a tool for improving livelihoods, improve poverty and advance economic development. Aslo the policymakers argue that the increased level of financial inclusion can have positive impact on economic growth, financial stability and reducing the 
grey economy. Positive effects include (Morgan and Pontines, 2014): diversification of bank assets, thereby reducing their riskiness; increased stability of their deposit base, reducing liquidity risks; and improved transmission of monetary policy. Negative effects include the erosion of credit standards (e.g., sub-prime), bank reputational risk, and inadequate regulation of MFIs. According to Morgan and Pontines there are positive effects of greater financial inclusion on financial stability, i.e., that the two are complementary rather than there being a trade-off between them. Studies show that small businesses benefit from access to credit, while the impact on the borrower's household's broader welfare might be more limited (Cull, Ehrbeck and Holle; 2014). Savings help households manage cash flow spikes, smooth consumption, as well as build working capital. Access to formal savings options can boost household welfare. Insurance can help poor households mitigate risk and manage shocks. New types of payment services can reduce transaction costs and seem to improve households' ability to manage shocks by sharing risks. Research also suggests that financial access improves local economic activity.

At the macroeconomic level, the empirical evidence shows that financial inclusion is positively correlated with growth and employment (Cull, Ehrbeck and Holle; 2014). The researchers generally believe in underlying causal impact. The main mechanisms they cite for doing so are generally lower transaction costs and better distribution of capital and risk across the economy. Evidence of a more preliminary nature suggests that broader access to bank deposits can also have a positive effect on financial stability that benefits the poor indirectly. In addition to the direct economic benefits, two recent developments suggest benefits for other government and private-sector efforts that might arise from inclusive lowcost, financial systems that reach a larger number of citizens. First, financial inclusion can improve the effectiveness and efficient execution of government payment of social safety net transfers (government-to-person payments), which play an important role in the welfare of many poor people. Second, financial innovation can significantly lower transaction costs and increase reach, which is enabling new private-sector business models that help address other development priorities.

Still the last research from the World Bank shows that country-specific characteristics play a central role in determining the impacts, interactions, and trade-offs between macroeconomic variables and policies. Thus, understanding the specic constraints generating lack of financial inclusion in an economy is critical for tailoring policy recommendations. Moreover, the model simulations indicate that different dimensions of financial inclusion have a differential impact on GDP and inequality and that there are trade-offs.

\section{Measure of the level of financial inclusion}

When building an index for financial inclusion in fact in the index should be included access indicators, usage indicators and quality measures (WB, 2015). The access indicators reflect the depth of outreach of financial services, such as the penetration of bank branches or point of sale (POS) devices in rural areas, or demand-side barriers that customers face to access financial institutions, such as cost or information. The usage indicators measure how clients use financial services, such as the regularity and duration of the financial product/ service over time (e.g. average savings balances, number of transactions per account, number of electronic payments made). The quality indicators are important because they describe 
whether financial products and services match clients' needs, the range of options available to customers, and clients' awareness and understanding of financial products. Most used global measures for financial inclusion are Global findex and indicators on GPFI.

The Global Financial Inclusion ("Global Findex”) database provides such indicators, measuring how adults in 148 countries around the world manage their day-to-day finances and plan for the future. The indicators are constructed using survey data from interviews with more than 150,000 nationally representative and randomly selected adults over the 2011 calendar year. The Global Findex indicators measure the use of financial services, which is distinct from access to financial services. Access most often refers to the supply of services, whereas use is determined by demand as well as supply factors (World Bank 2008a). The Global Findex data can shed light on the levels and patterns of use of different financial services both globally and among different groups, such as poor people, youth, and women. But one cannot assume that all those who do not use formal financial services are somehow constrained from participating in the formal financial sector-access and use are not the same thing.

The G20 and Global partnership for financial inclusion indicators include banked adults, adults with credit, banked enterprises, enterprises with outstanding loan and point if services. This index is similar to Findex but is more aggregative and uses same of the data that are used in Findex but also aggregate data from IMF and World Bank surveys. Same as the Findex index this index has the same main weakness, and measure the use of financial services but not the demand for financial services. Also, global indexes help to compare the level of financial inclusion in different country and time but better approach for single country is unique index that will reflects the characteristics of the country and will give better picture for the level of financial inclusion in the time line.

Survey that offers the most comprehensive global supply-side data on financial inclusion is the IMF Financial Access Survey (FAS). The FAS is a global survey that provides geographic and demographic data, offering a strong quantitative underpinning to research on the link between financial inclusion and economic growth. Because it has supply site data it overcomes the biggest weakness of Findex regarding the difference between access and usage of financial services.

Generally speaking there is empirical relationship which can be demonstrated between the economic development of a country and the level of financial inclusion. More developed countries have higher level of financial inclusion and vice versa. These findings suggest that financial depth and financial inclusion are related but ultimately distinct dimensions of financial development, and that financial systems can become deep without delivering access for all (Kunt, Klapper; 2013). 
Table 1 - Account penetration and GDP per capita and Formal Account Penetration, by Country Income Group
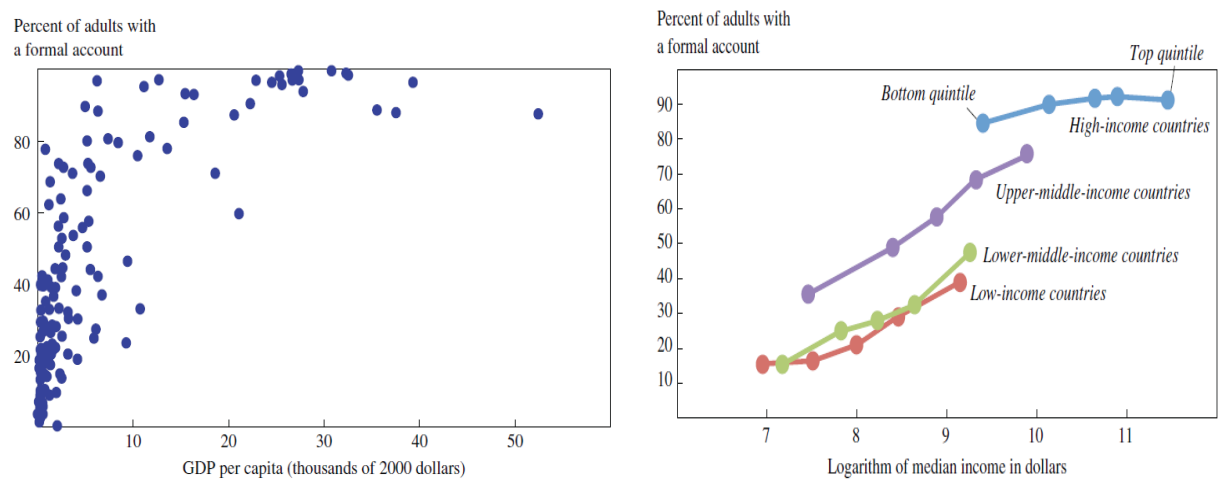

\section{Source: Demirguc-Kunt Asli and Klapper Leora.(2013). Measuring Financial Inclusion: Explaining Variation Across and Within Countries}

Globally, about 50 percent of adults have one or more bank accounts, and a nearly equal share are unbanked. In 2011, adults who were banked included the 9 percent of adults who received loans and the 22 percent of adults who saved through financial institutions (World Bank, 2015). Newly available user-side data show striking disparities in the use of financial services by individuals in developed and developing economies. For instance, the share of adults with a bank account in developed economies is more than twice the corresponding share in developing ones. The disparities are even larger if we examine the actual use of accounts. Worldwide, 44 percent of adults regularly use a bank account. However, if we focus on the bottom 40 percent of income earners in developing countries, we find that only 23 percent regularly use an account, which is about half the participation rate among the rest of the populations of these countries (the corresponding participation rates in developed economies are 81 percent and 88 percent, respectively) (Kunt, Klapper; 2013).

\section{Level of financial inclusion in Republic of Macedonia}

The basic idea that stands beside this paper is to evaluate the level of financial inclusion in R. Macedonia through analazysis of indicators in some basic categories like number of accounts, borrowed funds and payment services.

\section{Share of population with accounts}

The share of population that has transactional account is a basic indicator for the share of "banked" population. Other important question is the frequency of use on the account. As can be seen in table 2, the share of population with transactional account in Macedonia is on satisfactory level and above $72 \%$ of the population has transactional account. One of the factors that contribute for the satisfactory level is the legislation also. According to 
Macedonian laws in order to receive social transfer or subsidy for a government bodies you must have transactional account. Still there is descrepency in the share of population with accounts compared to Euro area.

Table 2 - Share of population with account

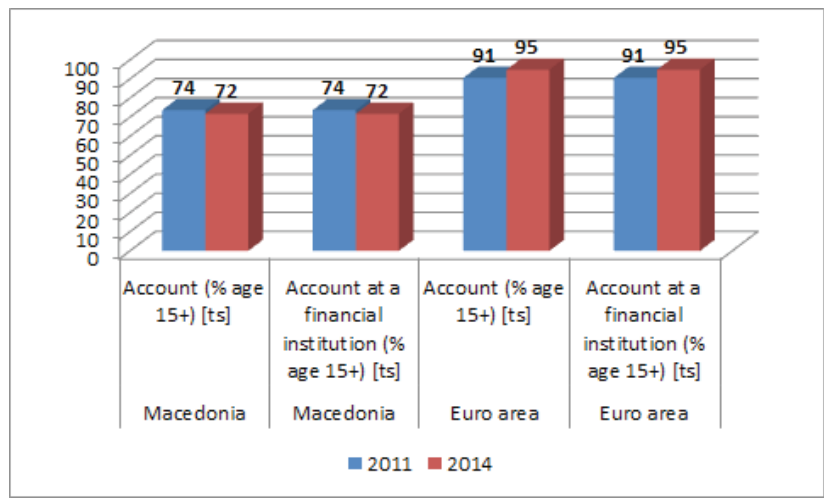

Source: World Bank Global Financial Inclusion Database (2014).

The data confirm the conclusions that aply in global terms regarding the share of population with accounts by gender, age and income.

Table 3 - Share of population with accounts by gender, income, age and area in Macedonia and Euro area

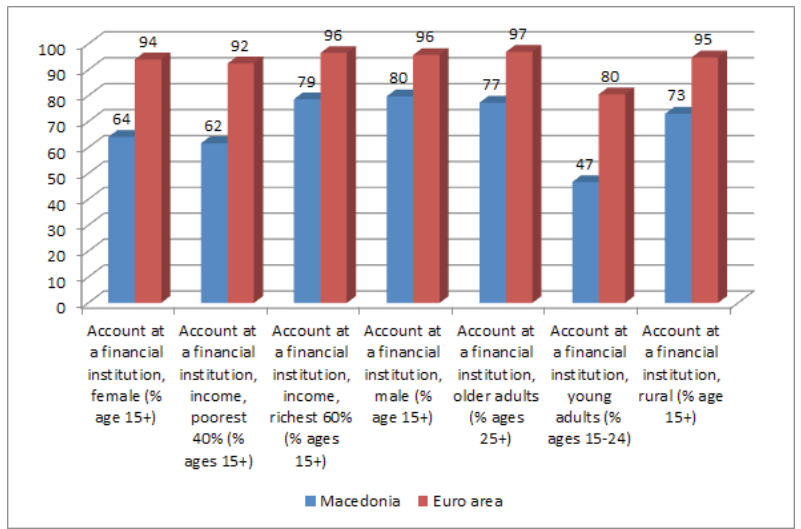

Source: World Bank Global Financial Inclusion Database (2014).

The shares of female population with accounts are by $16 \mathrm{pp}$ less than the male population. Also there is significant difference in the financial inclusion by income. Almoust $80 \%$ of the rischest $60 \%$ of the population have accounts and this percentige is only $62 \%$ at the poorest $40 \%$. Compared with Euro area the greatest diffrence is at the young population. Almost $80 \%$ of the young population in Euro area has account and this share in Macedonia is only $47 \%$. In some scale this is connected with the high level of unemployment at the yougest population. Regarding the level of education, the global trend is present in Macedonia also and more educated population is more likely to have account. 
Table 4-Share of population with accounts by gender and education

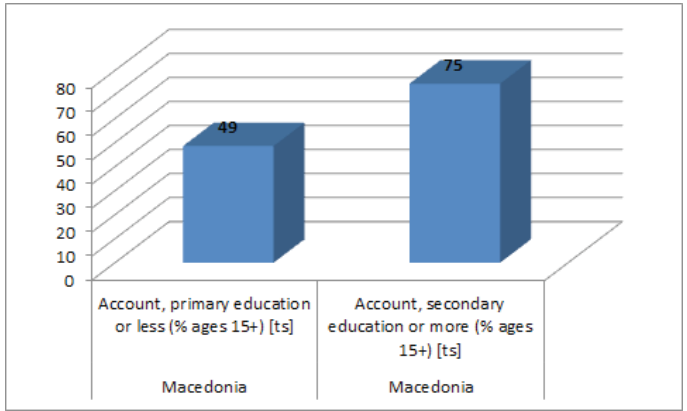

Source: World Bank Global Financial Inclusion Database (2014).

\section{Borrowed funds}

Having account is only one segment of financial inclusion and is not the best indicator for the effectivity of inclusion. Put in simple words you can have account but for whatever reason you are not using it then you are not part of the financial system. The share of population that effectively uses the financial system can show more clearly what the level of financial inclusion is. In that means the share of population that have deposits or loans from financial inclusion or even more that uses services from insurance companies is better indicator for the level of financial inclusion.

There is almoust no difference in the pecentige of population that borrowed any money in the Euro area and Macedonia. Aslo the gender structure doesn't show any significant differences. Significant differences can be point only at the young population. The young population in Macedonia doesn't have access or need to borrow money compared to the Euro area. In order to make full analasy for the inclusion what is more important is from whom and for what purposes the money is borrowed.

Table 5 - Share of population that borrowed money by different categories in Macedonia and Euro area

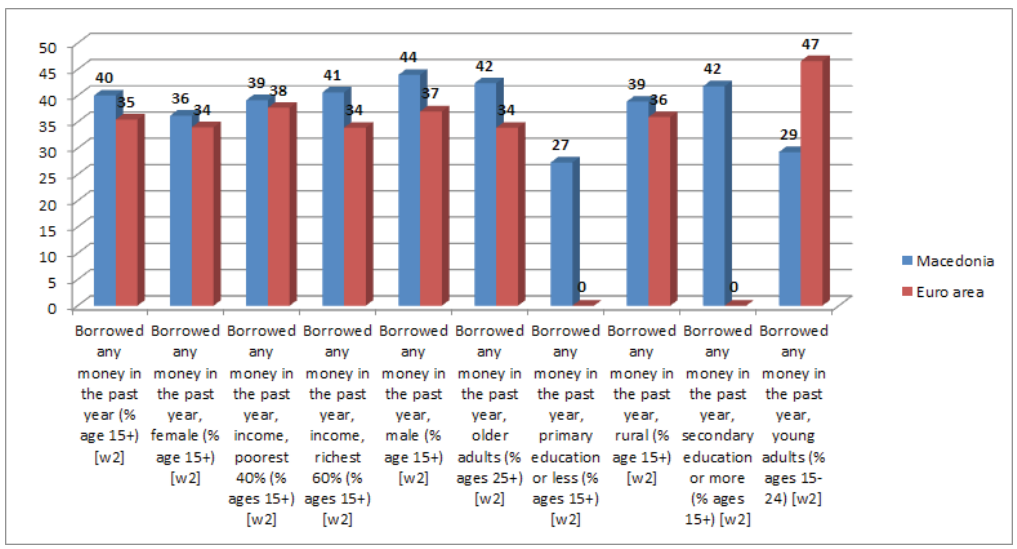

Source: World Bank Global Financial Inclusion Database (2014). 
The primary difference between Macedonia and the Euro area is the source of the borrowed funds. In Macedonia dominate friends and family and in the Euro area more funds are borrowed from financial institutions.

Table 6 - Share of population that borrowed money by different categories in Macedonia

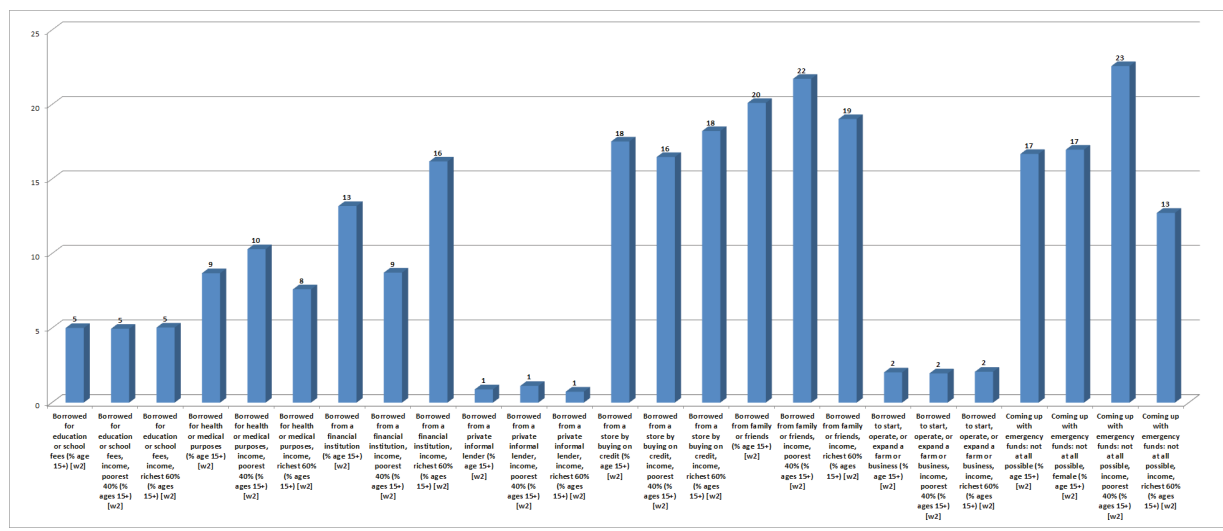

Source: World Bank Global Financial Inclusion Database (2014).

Although the difference in percentige from the popualtion that borrows fund from financial institution in Euro area and Macedonia is only 3 pp, still at the poorest $40 \%$ that difference is $5 \%$. This can indicate for reduced access of the poorest population in Macedonia in the financial system. Having in mind that banks dominate Macedonian banking system, they are very reluctant in granting loans to the poorest population. That can be seen from their granting rules where minimum income is perscribed. Almoust $20 \%$ of the population in Macedonia has borrowing from a store which is $7 \mathrm{pp}$ higher then the Euro Area. In this category there is no difference regarding the income level. Most used source of borrowings in Macedonia is friends and family. Especialy this source is more characteristic for the population with lower income level. Another important aspect when we analazy the financial inclusion and the borrowed funds is the purpose of the loans. The greatest difference, almoust double is in the share of population that borrowed funds for medical purposes. In Macedonia around $10 \%$ of the population above 15 years has borrowed funds for medical purposes and in the Euro Area this share is around 4\%. The poorest part of the population tends more to borrow for medical purposes. The percentige of population that needs to borrow funds for education is almoust the same in the Euro Area and Macedonia. Also almoust the same is the share of population that doesn't have emergency fund or it is not possible to come up with emergency fund and that rate is $18 \%$.

\section{Payments}

In order to further assess the level of finacial inclusion, aspects that must be seen are the freqency and needs for use of accounts and also other modern means of payment like credit cards, electronic banking or mobile phones. The difference in the usage of debit and credit cards shows more accurate picture about the level of financial inclusion. Altough there are some historical reasons for the greather usage of cash in Macedonia that are connected with the grey economy still the difference is obvious. 
Table 7 -Share of population with debit cards in Macedonia and Euro area

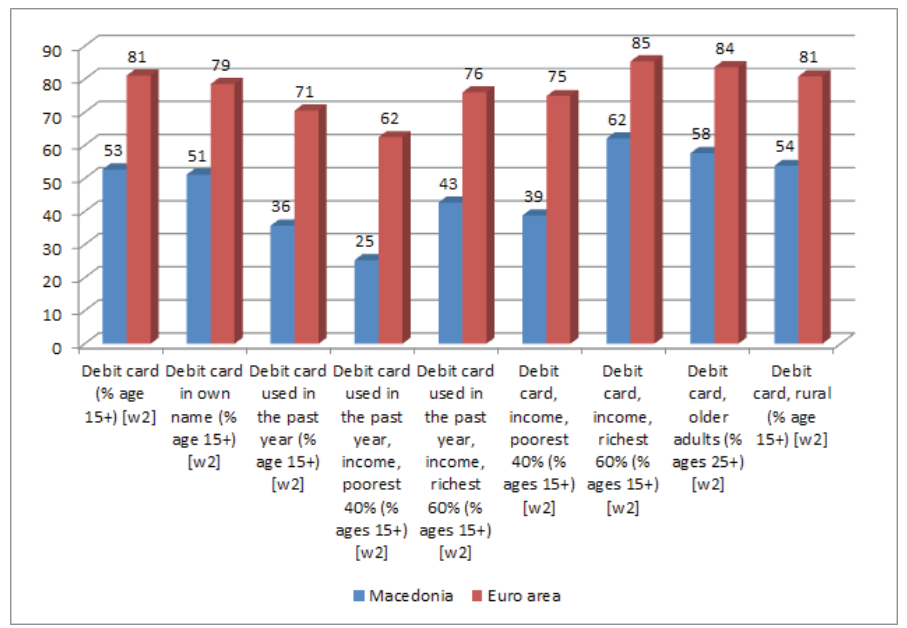

Source: World Bank Global Financial Inclusion Database (2014).

There is $30 \mathrm{pp}$ difference in the share of population that has debit card in Euro Area and Macedonia. This difference is evea greather when we analazy the usage. Only $36 \%$ of the population in Macedonia has used debit card in the past year and this percentige is only $25 \%$ at the pooriest $40 \%$. Main mode of withdrawal in Macedonia for $63 \%$ of the population is the ATM. So altough there is easy access for debit cards still there usage is not on satisfactory level. Off course this can be achieved by better financial education in which significant part can have the banking system. Also in order to increase the usage of cards is important the network of POS terminals.

The situation is simillar regarding the usage of credit cards. The difference between Euro Area andMacedonia is almoust double in all categories. It can be easily concluded that main diffrence can by made by the level of income.

Table 8 - Share of population with credit cards in Macedonia and Euro area

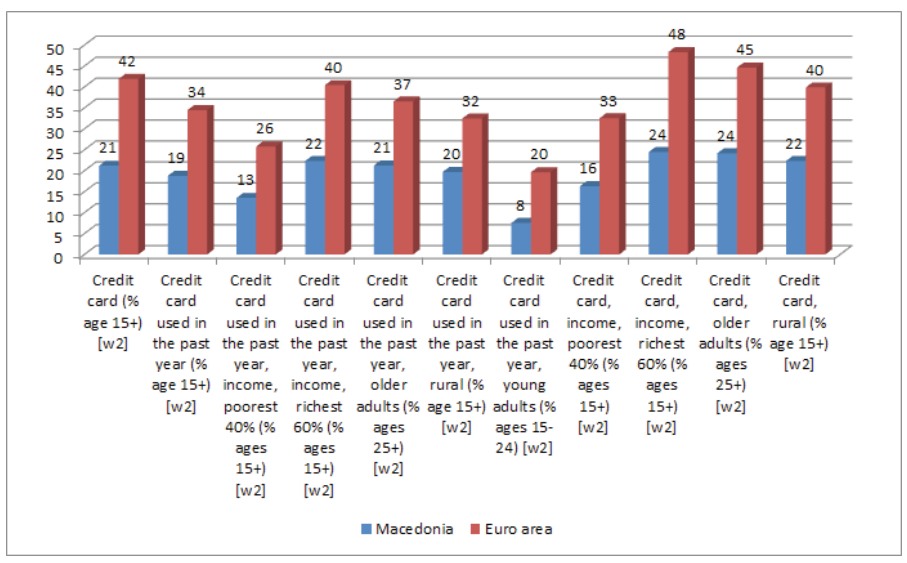

Source: World Bank Global Financial Inclusion Database (2014). 
The above mentioned conclusion can be further confirmed with deeper analazy of data. Almoust $90 \%$ of the population pays its bills in cash and that percentige in the Euro area is above $30 \%$. Also the percentiges of population that withdraw at once the whole government transfer or wage are much higher then on the same categories in Euro area. There are two main reasons for this kind of behavior, one of them are the habits and the other reason maybe is in less developed POS network.

Table 9 - Share of population in Macedonia and Euro area by ways of payment

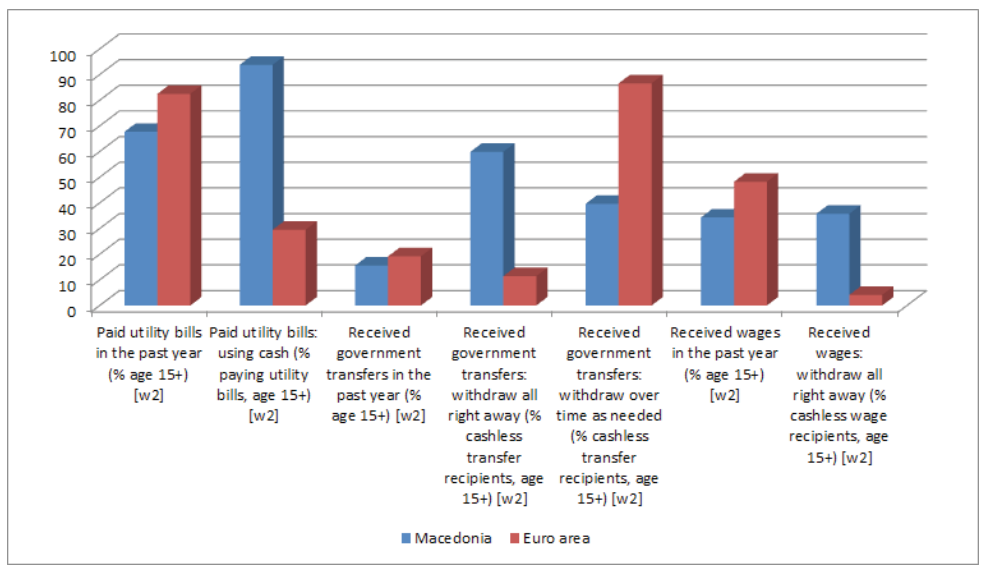

Source: World Bank Global Financial Inclusion Database (2014).

\section{Conclusion}

Financial inclusion is one of the most used words lately in the academic and financial world. In simple words the financial inclusion has one main goal, to provide access to financial services to parts of the population that are still unbanked. This is part of the population with lower level of income, that lives in rural areas, that is part of the grey economy ect. Why is the financial inclusion important issue? Because the estimation is that 2 billion adults worldwide don't have a basic account (World Bank, 2016). Also, More than 200 million formal and informal micro, small and medium-sized enterprises (MSMEs) in emerging economies lack adequate financing to thrive and grow. The main reason for enhancment of the level of financial inclusion is to reduce poverty. It is seen by policymakers as a tool for improving livelihoods, improve poverty and advance economic development. Aslo the policymakers argue that the increased level of financial inclusion can have positive impact on economic growth, financial stability and reducing the grey economy. Positive effects include (Morgan and Pontines, 2014): diversification of bank assets, thereby reducing their riskiness; increased stability of their deposit base, reducing liquidity risks; and improved transmission of monetary policy.

Generally speaking there is empirical relationship which can be demonstrated between the economic development of a country and the level of financial inclusion. More developed countries have higher level of financial inclusion and vice versa. The last Findex study (World Bank, 2015) shows that 94 percent of adults in OECD reported having an account in 2014. 
In developing economies only 54 percent did. There are also enormous disparities among developing regions, where account penetration ranges from 14 percent in the Middle East to 69 percent in East Asia and the Pacific.

The number of "banked population" in Macedonia measured through share of population with accounth is on satisfactory level and is above $70 \%$. There is still discrepency with the same indicator in the Euro area. Having in mind the low costs for opening account in Macedonia in order to further improve the use of accounts the main tool should be financial education. Especialy financial education should be focused on female population in rural areas and the young population between 15 and 27 years. In some scale the low level of young population with account is connected with the high level of unemployment at the yougest population and also with the grey economy.

Although the difference in percentige from the popualtion that borrows fund from financial institution in Euro area and Macedonia is only $3 \mathrm{pp}$, still at the poorest $40 \%$ that difference is $5 \%$. This can indicate for reduced access of the poorest population in Macedonia in the financial system. Having in mind that banks dominate Macedonian banking system, they are very reluctant in granting loans to the poorest population. That can be seen from their granting rules where minimum income is perscribed. Another important aspect when we analazy the financial inclusion and the borrowed funds is the purpose of the loans. The greatest difference, almoust double is in the share of population that borrowed funds for medical purposes. In Macedonia around $10 \%$ of the population above 15 years has borrowed funds for medical purposes and in the Euro Area this share is around 4\%. The poorest part of the population tends more to borrow for medical purposes. The percentige of population that needs to borrow funds for education is almoust the same in the Euro Area and Macedonia. Also almoust the same is the share of population that doesn't have emergency fund or it is not possible to come up with emergency fund and that rate is $18 \%$.

Regarding the payment methods, Macedonia is still cash society. There is $30 \mathrm{pp}$ difference in the share of population that has debit card in Euro Area and Macedonia. This difference is even greather when we analazy the usage. Only $36 \%$ of the population in Macedonia has used debit card in the past year and this percentige is only $25 \%$ at the pooriest $40 \%$. Main mode of withdrawal in Macedonia for $63 \%$ of the population is the ATM. So altough there is easy access for debit cards still there usage is not on satisfactory level. Off course this can be achieved by better financial education in which significant part can have the banking system. Also in order to increase the usage of cards is important the network of POS terminals. Almoust $90 \%$ of the population pays its bills in cash and that percentige in the Euro area is above $30 \%$. Also the percentiges of population that withdraw at once the whole government transfer or wage are much higher then on the same categories in Euro area. There are two main reasons for this kind of behavior, one of them are the habits and the other reason maybe is in less developed POS network. 


\section{References}

Cull, Robert; Ehrbeck, Tilman; Holle, Nina. (2014). Financial inclusion and development : recent impact evidence. CGAP focus note ; no. 92. Washington, DC ; World Bank Group.

Demirguc-Kunt Asli and Klapper Leora.(2013). Measuring Financial Inclusion: Explaining Variation Across and Within Countries.

http://www.afi-global.org/maya-declaration (15.12.2016)

http://www.centerforfinancialinclusion.org/our-definition-of-financial-inclusion (15.12.2016)

http://www.worldbank.org/en/topic/financialinclusion/brief/how-to-measure-financialinclusion (15.12.2016)

Karlan, Dean, and Jonathan Zinman. (2010). "Expanding Credit Access: Using Randomized Supply Decisions to Estimate the Impacts." Review of Financial Studies 23 (1): 433-64.

Morgan J. Peter and Pontines Victor.(2014). Financial Stability and Financial Inclusion. ADBI Working Paper Series. Paper 488. Tokyo: Asian Development Bank Institute.

Peter J. Morgan and Victor Pontines.(2014). Financial Stability and Financial Inclusion. ADBI Working Paper 488. Tokyo: Asian Development Bank Institute.

Thorsten Beck, Asli Demirguc-Kunt and Maria Soledad Martinez Peria. (2006).Banking Services for Everyone? Barriers to Bank Access and Use around the World. World Bank's research department, WPS4079.

United Nations Capital Development Fund. (2006). Building Inclusive Financial Sectors for Development, United Nations, New York, 2006

World Bank Global Financial Inclusion Database (2014)

World Bank. (2008). Access to Finance and Development: Theory and Measurement.

World Bank.(2015). The Global Findex Database 2014 : measuring financial inclusion around the world. WPS7255 